\title{
Role Of Board Size In Corporate Governance And Firm Performance Applying Pareto Approach, Is It Cultural Phenomena?
}

\author{
Maria Malik, Xi'an Jiaotong University, China \\ Difang Wan, Xi'an Jiaotong University, China \\ Muhammad Ishfaq Ahmad, The University of Lahore, Pakistan \\ Muhammad Akram Naseem, The University of Lahore, Pakistan \\ Ramiz Ur Rehman, The University of Lahore, Pakistan
}

\begin{abstract}
This paper examines the relationship between board size and firm performance. This relationship is tested in the light of Pareto Approach for Pakistani banking sector. For this purpose a sample of fourteen listed commercial banks of Pakistan are taken for analysis from 2008-2012 on the basis of their performance. Different econometric models are applied to test the relationship between bank performance variables and corporate governance practices in these banks. The results of this study are contradictory with the existing literature of corporate governance variables and firm performance. The most prominent result of this paper is the significant positive relationship between board size and bank performance. It is concluded in the findings that a large board size can enhance the bank performance in Pakistani scenario.
\end{abstract}

Keywords: Corporate Governance; Board Size; Bank Performance; Pareto

\section{INTRODUCTION}

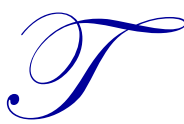

he role of corporate governance in today's corporate world is gaining importance day by day. That is the very reason academicians around the world are paying more attention developing and testing the existing and new practices of corporate governance. The evolution of new rules and codes of governance is a significant achievement of these researchers and practitioner, but there is still a huge gap in the development of new corporate governance codes for under developed countries which needs to be filled sooner in order to achieve better firm performance. Albeit, today's world is known as a global village but no one can apply the new set of governance rules for every part of the world. It is the fact that due to diverse culture, different financial environment, and heterogeneous legal frame work of the countries, these codes may not be useful for every country. In today's corporate world every country has to develop its own set of codes and rules of corporate governance.

The evolution process of corporate governance codes had started from the developed world and gradually passed on to developing countries. But no significant amount of work has been done for under developing countries in order to suggest news rules of corporate governance. In developed countries, the new codes of corporate governance are not only introduced but are practiced frequently in their corporate sectors. By practicing these new rules and codes of corporate governance the corporate sector of the western world is gaining success by significant increases in their firm performance. On the other hand, the same set of corporate governance rules do not give the same success to the corporate sector of the under developing countries. The reason is very obvious and logical that due to different financial and legal environments of under developing countries, one cannot get the same results from using those codes which are developed for western and civilized countries. In fact, this practice might create some serious consequences in these parts of the world in the form of disturbing foreign and domestic inflows. 
Un-doubtfully, corporate governance is the smooth and safe road for investors to achieve good results in term of profits and returns (Smith, 1996; Huson, 1997; Nesbitt, 1994; Carleton et al., 1998; Strickland et al., 1996). Corporate governance is defined in several ways; Organization for Economic Co-operation and Development (OCED) explained "Corporate governance involves a set of relationships between a company's management, its board, its shareholders and other stakeholders. Corporate governance also provides the structure through which the objectives of the company are set, and the means of obtaining those objectives and monitoring performance are determined." Cadbury Committee (1992) defined it as "The system by which companies are directed and controlled."

From the given explanation of corporate governance, one can understand that it's all about the protection of shareholders rights. It is very obvious that the shareholder has zero tolerance about firm performance. It is argued that the outcome of good governance is good performance (Yang, 2011; Andres, 2008; Tandelilin, 2007; Aebi el al., 2010). Things are very simple and straight as far as corporate governance practices and its importance is concerned, but things are complicated when different variables of corporate governance are taken under consideration like board size, number of meetings in a year, profile of CEO, ownership structure, etc. No doubt all these variables have their due importance but their combination is very critical for achieving good governance and better performance. This issue got academicians attention very promptly and many researchers have come up with different and interesting results. Every author has defended his findings in a very logical and sophisticated way.

This paper contributes something new and interesting in the existing debate of corporate governance codes by borrowing one famous economic theory: Economic Pareto Efficiency (1848-1923) theory. This theory explains that it is impossible to make any individual better off without making at least one individual worse off. This paper is motivated by this theory and its application in Pakistan's financial market. Pakistan is an under developing country that is sixty four years old. It is a common fact that, more or less, all under developing countries are not good at governance. So Pakistan is not an exception. In the Pakistan corporate sector, one local term is very commonly used which needs to be defined; i.e., "Seith Culture" or "Vedera Culture" which means a group of people who have a lot of money and authority in the society and they can run their own businesses in their own style. Due to this culture they appoint their likeminded people as members of the board of directors. Later, those directors implement "Seith" agenda and protect Seith's (an individual with a specific approach and mind set) interest at the cost of minority shareholders rights. The number of studies in the western world suggested that smaller board size can enhance firm performance; e.g., Jensen (1993) suggests that board sizes in the U.S. tend to be too large and should not be more than 8 directors. This may be true for developed economies but might not be true for under developing countries like Pakistan.

That is the very reason this study suggests opposite model for Pakistan. For this purpose a sample of Pakistani private and state owned commercial banks is taken for analysis. These banks are further classified into conventional and Islamic banks. Pakistan has been introducing a liberal and efficient financial market since 1980 (State Bank of Pakistan, 1980) by privatizing state-owned banks and encouraging new domestic and foreign entries into the market. Apart from these financial reforms, a Code of Corporate Governance has been implemented to all listed companies in Pakistan to encourage good governance in 2002, which was introduced by the Securities Exchange of Pakistan. The rest of the paper consists of following parts: Part 2 includes review of literature, Part 3 explains data and methodology, and finally Part 4 discusses the findings and conclusion.

\section{REVIEW OF LITERATURE}

The relationship between corporate governance, especially board size and firm performance, is still a fundamental issue for researchers. Prior studies in this context put more focus on the performance but ignore the cultural phenomena (Demsetz \& Lehn, 1985; Morck et al., 1988). This study extends the literature with this hypothesis that a firm with larger board size has a positive relationship with its performance under specific cultural aspects.

There is a consensus among academicians that a large board size causes a coordination problem between members. Jensen (1993) suggests that board sizes in the U.S. tend to be too large and should not be more than 8 directors. On the other hand, there may be a tradeoff between coordination cost and prospective ideas. If we ignore 
the coordination cost, a large board size can add more ideas to the board which may be beneficial for the firm in the decision making process.

In some cultures, businesses are controlled by small dominated groups like family members and they run their business for their own interest; this fact has encouraged some scholars to study the influence of such boards on firms performance (Claessens et al., 2002; Villalonga \& Amit, 2006; Dalton et al., 1998). The Pareto Efficiency (1848-1923) theory explains the phenomena that it is impossible to make any one individual better off without making at least one individual worse off. This paper also argues that board of directors are always making decisions just for the betterment of themselves and making the minority shareholders worse off. Especially in Pakistan, company directors have their own side businesses and they often make decisions to get benefits of their own side businesses. Particularly in the case of the Pakistani banking industry, directors sanctioned risky loans to their own side businesses at the cost of minority shareholders stakes. All these bad decisions may lead to bad firm performance (Anderson \& Reeb, 2003; Ang et al., 2000; Bennedsen et al., in press; McConaughy et al., 1998; Cronqvist \& Nilsson, 2003; Maury, 2006; Villalonga \& Amit, 2006).

In developed countries it may be true that family ownership enhances the performance of the firms due to their cultural phenomena as they have sophisticated and well developed mechanisms (Anderson \& Reeb, 2003, 2004; McConaughy et al., 1998; Villalonga \& Amit, 2006). But in under developing countries like Pakistan where things are at a growing stage it is entirely opposite of developed nations (Claessens et al., 2002; Cronqvist \& Nilsson, 2003; Maury, 2006; Bennedsen et al., in press). In this article, we argue that it is a cultural phenomenon that a large board size can increase firms performance because a large board size might be a hurdle for a smaller group who wants to do all the ill-doing at the cost of minority shareholders right.

\section{DATA AND ESTIMATION}

In this section we explain the data sources of governance variables and performance.

\subsection{Sample of Data}

The Pakistani banking industry is the combination of commercial banks, specialized banks, and stateowned banks. On the basis of bank performance, a sample of fourteen banks is selected which include commercial banks, micro finance banks, and insurance companies. The selected banks also include state owned, private, and Islamic banks which are listed on the local Karachi stock exchange. The financial data of the selected banks are taken from the annual published financial reports by the State Bank of Pakistan for the period of 2008-2012. This time period is important for the Pakistani banking sector because most of the corporate governance codes are drafted and implemented during this time span.

\subsection{Governance and Performance Variables}

Return on equity (ROE), return on asset (ROA), and earning per share (EPS) are taken as proxies for bank performance. In the suggested econometric models these variables are computed as dependent variables. For the corporate governance variables, board size, number of meetings held, size of audit committee, and number of shareholders are used.

\subsection{Descriptive Statistics}

Table 1 highlights the descriptive statistics of governance and performance variables with to banks category. 
Table 1: State Owned Banks

\begin{tabular}{|c|c|c|c|c|c|}
\hline \multicolumn{3}{|c|}{ Descriptive Statistics } & Max & Min & Stdev \\
\hline \multirow{4}{*}{ Bank of Punjab } & Average & 8 & 10 & 7 & 1.30 \\
\cline { 2 - 6 } & No.of Meeting & 10 & 13 & 4 & 3.36 \\
\cline { 2 - 6 } & Size Of Audit & 3 & 4 & 3 & 0.45 \\
\cline { 2 - 6 } & Total Shares Held & 528797376 & 528797376 & 528797376 & 0.00 \\
\cline { 2 - 6 } & No.of Shareholders & 19635.8 & 20641 & 18312 & 849.28 \\
\cline { 2 - 6 } & ROE & -8.44 & 22.52 & -61.13 & 34.24 \\
\cline { 2 - 6 } & ROA & -0.13 & 0.64 & -1.50 & 0.87 \\
\cline { 2 - 6 } & Earning Per Shares (Million) & -8.39 & 3.09 & -19.04 & 10.49648894 \\
\cline { 2 - 6 } & Board Size & 7 & 8 & 6 & 0.71 \\
\cline { 2 - 6 } & No.of Meeting & 7 & 8 & 5 & 0.30 \\
\cline { 2 - 6 } & Size Of Audit & 4 & 5 & 4 & 221571232.31 \\
\cline { 2 - 6 } & Total Shares Held & 624918957 & 900262030 & 400406896 & 1696.70 \\
\cline { 2 - 6 } & No.of Shareholders & 34804.2 & 36621 & 32560 & 9.43 \\
\cline { 2 - 6 } & ROE & 3.88 & 10.00 & -12.00 & 1.27 \\
\cline { 2 - 6 } & ROA & 0.48 & 1.30 & -1.70 & 1.08 \\
\cline { 2 - 6 } & Earning Per Shares (Million) & 0.52 & 1.29 & -1.27 & \\
\hline
\end{tabular}

The Pakistani banking sector had undergone phenomenon financial and structural reforms during the last two decades. The first phase of the financial sector reform was introduced in 1990 in which privatization was the main objective. During this reform from 1992-1996, state owned banks were partially privatized which later on were completely privatized in second phase reforms during 1997-2000. In Table 1, statistics show why state owned banks privatized. At this time there are only four state owned banks in Pakistan, but their efficiency and output is not satisfactory. The main reason behind this fact is simply bad governance. If we look at the return on equity of state owned banks it's even worse (Berger, Hasan, \& Klapper, 2004; Bhattacharya, Lovell, \& Sahay, 1997; Isik \& Hassan, 2002). If they do not generate good profits they cannot survive in the market.

Table 1.1: Islamic Banks

\begin{tabular}{|c|c|c|c|c|c|}
\hline \multicolumn{6}{|c|}{ Descriptive Statistics } \\
\hline & ompany Name & Average & Max & Min & Stdev \\
\hline \multirow{8}{*}{ Bank Islami } & Board Size & 8 & 10 & 7 & 1.30 \\
\hline & No.of Meeting & 6 & 7 & 5 & 0.84 \\
\hline & Size Of Audit & 3 & 5 & 3 & 0.89 \\
\hline & Total Shares Held & 527967898 & 527967898 & 527967898 & 0.00 \\
\hline & No.of Shareholders & 25936.6 & 27863 & 24386 & 1359.82 \\
\hline & ROE & 1.14 & 8.29 & -9.93 & 7.46 \\
\hline & ROA & -0.13 & 0.79 & -1.84 & 1.05 \\
\hline & Earning Per Shares (Million) & 0.12 & 0.78 & -0.93 & 0.71 \\
\hline \multirow{8}{*}{ Meezan Bank } & Board Size & 10 & 11 & 9 & 0.84 \\
\hline & No.of Meeting & 4 & 5 & 4 & 0.55 \\
\hline & Size Of Audit & 3 & 3 & 3 & 0.00 \\
\hline & Total Shares Held & 712443361 & 903367473 & 492596158 & 154463447.45 \\
\hline & No.of Shareholders & 2022.6 & 2324 & 1821 & 191.78 \\
\hline & ROE & 18.55 & 28.18 & 10.30 & 7.51 \\
\hline & ROA & 1.27 & 1.90 & 0.82 & 0.43 \\
\hline & Earning Per Shares (Million) & 2.50 & 3.88 & 1.22 & 1.23 \\
\hline
\end{tabular}

In response to liberalization reforms in financial sectors, many new banks came into the industry with new developments and strategies. That made the financial sector more competitive and forced the existing players of the market to come up with new products and innovations. Evolution of Islamic banking in Pakistan is the result of this competitiveness. Due to the increasing trend of Islamic banking in Pakistan, some new investors encouraged and introduced specialized Islamic banks. These Islamic banks are yet to define the explicit difference between Islamic 
and conventional banking, even though people showed positive attitudes toward them. In return, Islamic banks showed some satisfactory outcomes which are quite opposite to the state- owned banks. This is the strong evidence of good governance because in the Pakistani environment these banks are new and people don't have the clear vision of true Islamic banking. Despite the fact that Islamic banks market share is competitively low as compared to other conventional banks but for Islamic banking there is an opportunity of growth which is associated with true Islamic culture (Rosly \& Abu Bakar, 2003; Yudistira, 2004).

Table 1.2: Private Banks

\begin{tabular}{|c|c|c|c|c|c|}
\hline \multicolumn{6}{|c|}{ Descriptive Statistics } \\
\hline & ompany Name & Average & Max & Min & Stdev \\
\hline \multirow{8}{*}{ Allied Bank } & Board Size & 10 & 12 & 9 & 1.30 \\
\hline & No.of Meeting & 8 & 10 & 6 & 1.82 \\
\hline & Size Of Audit & 3 & 4 & 3 & 0.55 \\
\hline & Total Shares Held & $6.34 \mathrm{E}+08$ & $9.46 \mathrm{E}+08$ & 86031092 & 326283093.58 \\
\hline & No.of Shareholders & 20229 & 20810 & 19772 & 436.59 \\
\hline & ROE & 0.28 & 0.31 & 0.21 & 0.04 \\
\hline & ROA & 0.02 & 0.02 & 0.01 & 0.00 \\
\hline & Earning Per Shares (Million) & 8.73 & 12.34 & 4.39 & 3.05 \\
\hline \multirow{8}{*}{ Askari Bank } & Board Size & 11 & 13 & 10 & 1.30 \\
\hline & No.of Meeting & 10 & 13 & 4 & 3.65 \\
\hline & Size Of Audit & 3 & 4 & 3 & 0.55 \\
\hline & Total Shares Held & $6.15 \mathrm{E}+08$ & $8.13 \mathrm{E}+08$ & $4.06 \mathrm{E}+08$ & 161082725.68 \\
\hline & No.of Shareholders & 20756.8 & 22259 & 19231 & 1131.05 \\
\hline & ROE & 6.67 & 9.64 & 3.06 & 2.43 \\
\hline & ROA & 0.37 & 0.49 & 0.20 & 0.12 \\
\hline & Earning Per Shares (Million) & 1.69 & 2.30 & 0.95 & 0.55 \\
\hline \multirow{8}{*}{ Bank-Alfalah } & Board Size & 11 & 13 & 9 & 1.58 \\
\hline & No.of Meeting & 5 & 6 & 4 & 0.84 \\
\hline & Size Of Audit & 4 & 6 & 4 & 0.89 \\
\hline & Total Shares Held & $1.24 \mathrm{E}+09$ & $1.35 \mathrm{E}+09$ & $8 \mathrm{E}+08$ & 245813747.85 \\
\hline & No.of Shareholders & 20508.8 & 26856 & 16800 & 4252.53 \\
\hline & ROE & 10.93 & 18.90 & 4.90 & 6.45 \\
\hline & ROA & 0.51 & 0.91 & 0.24 & 0.32 \\
\hline & Earning Per Shares (Million) & 1.76 & 3.38 & 0.71 & 1.19 \\
\hline \multirow{8}{*}{ Faysal Bank } & Board Size & 12 & 13 & 10 & 1.14 \\
\hline & No.of Meeting & 5 & 6 & 4 & 0.84 \\
\hline & Size Of Audit & 3 & 4 & 3 & 0.45 \\
\hline & Total Shares Held & $7.24 \mathrm{E}+08$ & $9.27 \mathrm{E}+08$ & $5.3 \mathrm{E}+08$ & 160030875.32 \\
\hline & No.of Shareholders & 14856.2 & 17494 & 12947 & 2309.15 \\
\hline & ROE & 4.57 & 10.57 & 0.80 & 4.80 \\
\hline & ROA & 9.16 & 11.18 & 7.43 & 1.76 \\
\hline & Earning Per Shares (Million) & 1.34 & 1.53 & 1.20 & 0.12 \\
\hline \multirow{8}{*}{ KASB } & Board Size & 12 & 14 & 9 & 2.07 \\
\hline & No.of Meeting & 7 & 8 & 5 & 1.22 \\
\hline & Size Of Audit & 4 & 4 & 3 & 0.55 \\
\hline & Total Shares Held & $1.18 \mathrm{E}+09$ & $1.95 \mathrm{E}+09$ & $4.01 \mathrm{E}+08$ & 729213059.04 \\
\hline & No.of Shareholders & 11112.5 & 20343.5 & 8127 & 5176.31 \\
\hline & ROE & -63.81 & -11.04 & -110.02 & 38.67 \\
\hline & ROA & -3.65 & -1.20 & -7.10 & 2.37 \\
\hline & Earning Per Shares (Million) & -2.37 & -0.55 & -4.45 & 1.45 \\
\hline \multirow{5}{*}{ MCB } & Board Size & 13 & 15 & 12 & 1.30 \\
\hline & No.of Meeting & 5 & 6 & 4 & 1.00 \\
\hline & Size Of Audit & 5 & 6 & 4 & 0.84 \\
\hline & Total Shares Held & $7.8 \mathrm{E}+08$ & $9.2 \mathrm{E}+08$ & $6.91 \mathrm{E}+08$ & 98639767.37 \\
\hline & No.of Shareholders & 42839.6 & 44131 & 41269 & 1356.06 \\
\hline
\end{tabular}


Table 1.2 cont.

\begin{tabular}{|c|c|c|c|c|c|}
\hline & & & & & \\
\hline & $\mathrm{ROE}$ & 27.21 & 31.49 & 25.07 & 2.53 \\
\hline & ROA & 3.22 & 3.60 & 2.95 & 0.24 \\
\hline & Earning Per Shares (Million) & 19.16 & 22.77 & 16.71 & 2.69 \\
\hline \multirow{8}{*}{ NIB Bank } & Board Size & 11 & 14 & 9 & 1.92 \\
\hline & No.of Meeting & 6 & 7 & 5 & 1.00 \\
\hline & Size Of Audit & 3 & 3 & 3 & 0.00 \\
\hline & Total Shares Held & $6.31 \mathrm{E}+09$ & $1.03 \mathrm{E}+10$ & $2.84 \mathrm{E}+09$ & 3680105988.39 \\
\hline & No.of Shareholders & 29030.2 & 31993 & 27222 & 1946.82 \\
\hline & ROE & -21.22 & 1.66 & -74.02 & 30.89 \\
\hline & ROA & -2.26 & 0.33 & -6.15 & 2.81 \\
\hline & Earning Per Shares (Million) & -1.06 & 0.17 & -2.63 & 1.39 \\
\hline \multirow{8}{*}{ Soneri Bank } & Board Size & 12 & 14 & 10 & 1.79 \\
\hline & No.of Meeting & 8 & 9 & 6 & 1.30 \\
\hline & Size Of Audit & 4 & 5 & 4 & 0.55 \\
\hline & Total Shares Held & $6.84 \mathrm{E}+08$ & $1 \mathrm{E}+09$ & $4.11 \mathrm{E}+08$ & 256573148.82 \\
\hline & No.of Shareholders & 9829 & 10119 & 9598 & 213.85 \\
\hline & ROE & 6.58 & 10.63 & 1.61 & 4.42 \\
\hline & ROA & 0.52 & 0.89 & 0.12 & 0.36 \\
\hline & Earning Per Shares (Million) & 0.84 & 1.70 & 0.17 & 0.63 \\
\hline \multirow{8}{*}{ Summit Bank } & Board Size & 11 & 13 & 10 & 1.30 \\
\hline & No.of Meeting & 6 & 7 & 5 & 0.89 \\
\hline & Size Of Audit & 3 & 3 & 3 & 0.00 \\
\hline & Total Shares Held & $8.49 \mathrm{E}+08$ & $1.08 \mathrm{E}+09$ & $5 \mathrm{E}+08$ & 246066335.41 \\
\hline & No.of Shareholders & 47854.1 & 52288 & 37553.5 & 6044.55 \\
\hline & ROE & -50.80 & -3.11 & -94.38 & 39.12 \\
\hline & ROA & -2.93 & -0.77 & -5.41 & 2.32 \\
\hline & Earning Per Shares (Million) & -2.76 & -0.38 & -5.58 & 2.13 \\
\hline \multirow{8}{*}{ UBL } & Board Size & 12 & 14 & 10 & 1.58 \\
\hline & No.of Meeting & 6 & 6 & 5 & 0.45 \\
\hline & Size Of Audit & 4 & 4 & 4 & 0.00 \\
\hline & Total Shares Held & $1.16 \mathrm{E}+09$ & $1.22 \mathrm{E}+09$ & $1.01 \mathrm{E}+09$ & 95606083.36 \\
\hline & No.of Shareholders & 27301 & 29307 & 24924 & 2004.74 \\
\hline & ROE & 21.84 & 24.30 & 19.50 & 2.19 \\
\hline & ROA & 1.80 & 2.20 & 1.50 & 0.33 \\
\hline & Earning Per Shares (Million) & 10.60 & 14.71 & 8.24 & 2.93 \\
\hline
\end{tabular}

The market share of private banks in the industry is considerably high. This is all because of liberalization and privatization reform introduced by the State Bank of Pakistan. Many players participated in this rapid growth and earned significant profits. But in a very short period of time, these banks realized the importance of corporate governance practice especially when they had competition with foreign banks. Table 1.2 shows a very satisfactory image of the private banks as compared to both state-owned and Islamic banks. Several researchers confirm this fact (Boubakri et al., 2005b; Boubakri, Cosset, \& Guedhami, 2009; Clarke et al., 2005; Lin \& Zhang, 2009). Several believe that the privatization improves the performance of a bank (Boubakri, Cosset, \& Guedhami, 2005; Fries \& Taci, 2005; Clarke et al., 2005; Beck, Cull, \& Jerome, 2005; Bonin et al., 2005).

From the above mentioned descriptive results one can conclude that a bank, no matter if it is conventional or Islamic, has a large board size then its profit is better than a bank that has a small board size.

\subsection{Estimation of Relationship Between Performance and Governance}

Table 2 comprises our results of relationship between performance and governance ignoring the bank type. 
Table 2

\begin{tabular}{|l|c|c|c|c|}
\hline \multicolumn{9}{|c|}{ Correlations } & \multicolumn{2}{c|}{ Number of Meetings } \\
\hline \multirow{4}{*}{ Pearson Correlation } & Return on Equity in \% & 1.00 & 0.37 & -0.22 \\
\cline { 2 - 5 } & Board Size & 0.37 & 1.00 & 0.09 \\
\cline { 2 - 5 } & Number of Meetings & -0.22 & 0.09 & 1.00 \\
\cline { 2 - 5 } & Audit Committee size & 0.24 & 0.18 & 0.00 \\
\hline \multirow{3}{*}{ Sig. (1-tailed) } & Return on Equity in \% &. & $0.00^{* *}$ & 0.03 \\
\cline { 2 - 5 } & Board Size & 0.00 & 0.24 & 0.24 \\
\cline { 2 - 5 } & Number of Meetings & 0.03 & 0.07 &. \\
\cline { 2 - 5 } & Audit Committee size & $0.02^{* *}$ & & 0.50 \\
\hline
\end{tabular}

** Significant at alpha 5\%

The findings of Table 2 suggest that governance does matter for bank performance which is in accordance with existing literature (Smith, 1996; Huson, 1997; Nesbitt, 1994; Carleton et al., 1998; Strickland et al., 1996). An interesting finding in Table 2 is that there is a negative correlation between the number of meetings and the return of equity (Vafeas, 1999) but has a positive relationship between board size. This is true in the sense that board meetings carry different costs like managerial time, travel expense, and meetings fees. In the case of board size it is very encouraging for external participants to become the part of the board and increase the firm performance (Weisbach, 1988; Byrd \& Hickman, 1992; Brickley et al., 1994; Borokhovich et al., 1996; Cotter et al., 1997). Secondly we find positive correlation between audit committee and firm performance which is also theoretically true. Due to a strong audit committee, firms can achieve better performance (Belkhir, 2009; Vallelado et al., 2008; James, 1987; Xie et al., 2003; Lin, 2006, Klein, 2004).

\subsection{Governance Influence on ROE, ROA, \& EPS}

Governance influence on performance (ROE, ROA, \& EPS) has been tested through linear regression models as given below.

$$
\begin{aligned}
& \mathrm{ROE}=\alpha+\beta B S+\beta 2 A C+\beta 3 N M+\epsilon \\
& \mathrm{ROA}=\alpha+\beta B S+\beta 2 A C+\beta 3 N M+\epsilon \\
& \mathrm{EPS}=\alpha+\beta B S+\beta 2 A C+\beta 3 N M+\epsilon
\end{aligned}
$$

where:

ROE (Return on Equity), ROA (Retune on Asset), EPS (Earning per share), BS (Board Size), AC (Audit Committee) and NM (Number of meetings)

\begin{tabular}{|c|c|c|c|c|c|c|c|c|c|c|}
\hline \multicolumn{11}{|c|}{ Model Summary } \\
\hline Model & $\mathbf{R}$ & \multicolumn{2}{|c|}{ R Square } & \multicolumn{2}{|c|}{ Adjusted R Square } & \multicolumn{3}{|c|}{ Std. Error of the Estimate } & \multicolumn{2}{|c|}{ Durbin-Watson } \\
\hline $1^{*}$ & 0.47 & \multicolumn{2}{|c|}{0.22} & \multicolumn{2}{|c|}{0.19} & \multicolumn{3}{|c|}{27.80} & \multicolumn{2}{|c|}{2.1} \\
\hline \multicolumn{11}{|c|}{ ANOVA } \\
\hline Model & & \multicolumn{2}{|c|}{ Sum of Squares } & \multicolumn{2}{|c|}{ df } & \multicolumn{2}{|l|}{ Mean Square } & $\mathbf{F}$ & \multicolumn{2}{|c|}{ Sig. } \\
\hline \multirow[t]{3}{*}{$1^{*}$} & Regression & \multicolumn{2}{|c|}{15039.67} & \multicolumn{2}{|c|}{3} & \multicolumn{2}{|l|}{5013.22} & 6.48 & \multicolumn{2}{|c|}{$0.00^{* * *}$} \\
\hline & Residual & \multirow{2}{*}{\multicolumn{2}{|c|}{$\begin{array}{l}51032.23 \\
6607190\end{array}$}} & \multicolumn{2}{|c|}{66} & \multicolumn{2}{|l|}{773.22} & & & \\
\hline & Total & & & & & & & & & \\
\hline \multicolumn{11}{|c|}{ Coefficients } \\
\hline \multirow{2}{*}{ Model } & & & \multicolumn{2}{|c|}{$\begin{array}{c}\text { Un-standardized } \\
\text { Coefficients }\end{array}$} & \multicolumn{2}{|c|}{ Standardized Coefficients } & $\mathbf{T}$ & Sig. & \multicolumn{2}{|c|}{$\begin{array}{c}\text { Collinearity } \\
\text { Statistics }\end{array}$} \\
\hline & & & & & Std. Error & Beta & & & Tolerance & VIF \\
\hline \multirow[t]{4}{*}{$1^{*}$} & \multicolumn{2}{|c|}{ (Constant) } & \multicolumn{2}{|c|}{-62.05} & 23.59 & & -2.63 & 0.01 & & \\
\hline & \multirow{2}{*}{\multicolumn{2}{|c|}{$\begin{array}{c}\text { Board Size } \\
\text { Number of Meetings }\end{array}$}} & \multicolumn{2}{|c|}{6.46} & 2.01 & 0.35 & 3.21 & $0.00^{* * *}$ & 0.96 & 1.04 \\
\hline & & & & .59 & 1.55 & -0.25 & -2.32 & $0.02^{* *}$ & 0.99 & 1.01 \\
\hline & Audit Commi & e Size & & 02 & 4.38 & 0.18 & 1.60 & 0.11 & 0.97 & 1.03 \\
\hline
\end{tabular}

\subsection{Governance and Return on Equity}

Table 3 
The above stated findings revealed that there is a significance relationship between return on equity and corporate governance variables. The overall $\mathrm{P}$ value of the model is $<5 \% \& 1 \%$ which shows that the overall model is significant (Smith, 1996; Huson, 1997; Nesbitt, 1994; Carleton et al., 1998; Strickland et al., 1996). P-value of board size and number of meetings < 5\% show that both are significantly positively and negatively related to return on equity respectively (Alexander, Fennell, \& Halpern, 1993; Goodstein, Gautam, \& Boeker, 1994).

Table 3 cont.

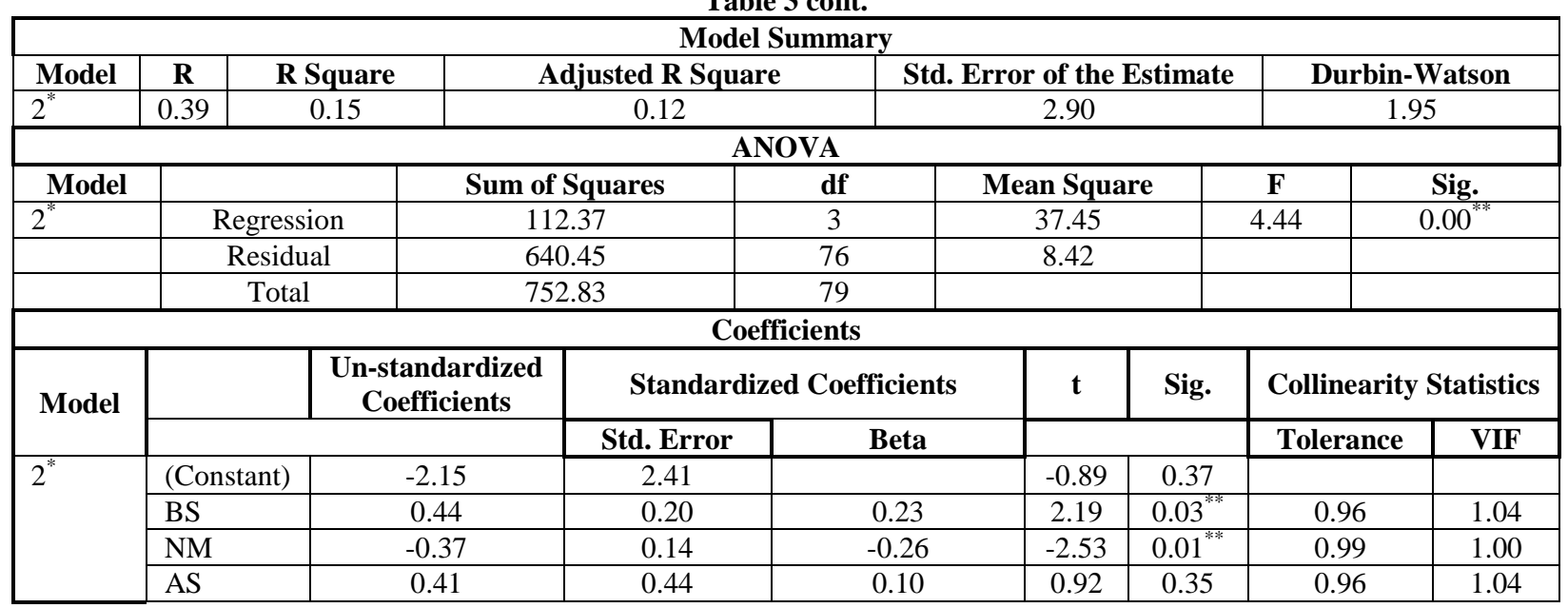

* Model 2; ** significance at alpha $5 \%$

The second model is also showing the expected results as corporate governance variables have influence on return on assets. Both board size and the number of meetings are significantly positively and negatively associated with return on asset respectively as P-value of both variables are < 5\% (Mintz-berg, 1983; Pfeffer, 1972, 1973). RSquare value 0.12 and Durbin-Watson value 1.95 give more strength to the results in concluding that corporate governance variables have influence on return on asset.

Table 3 cont.

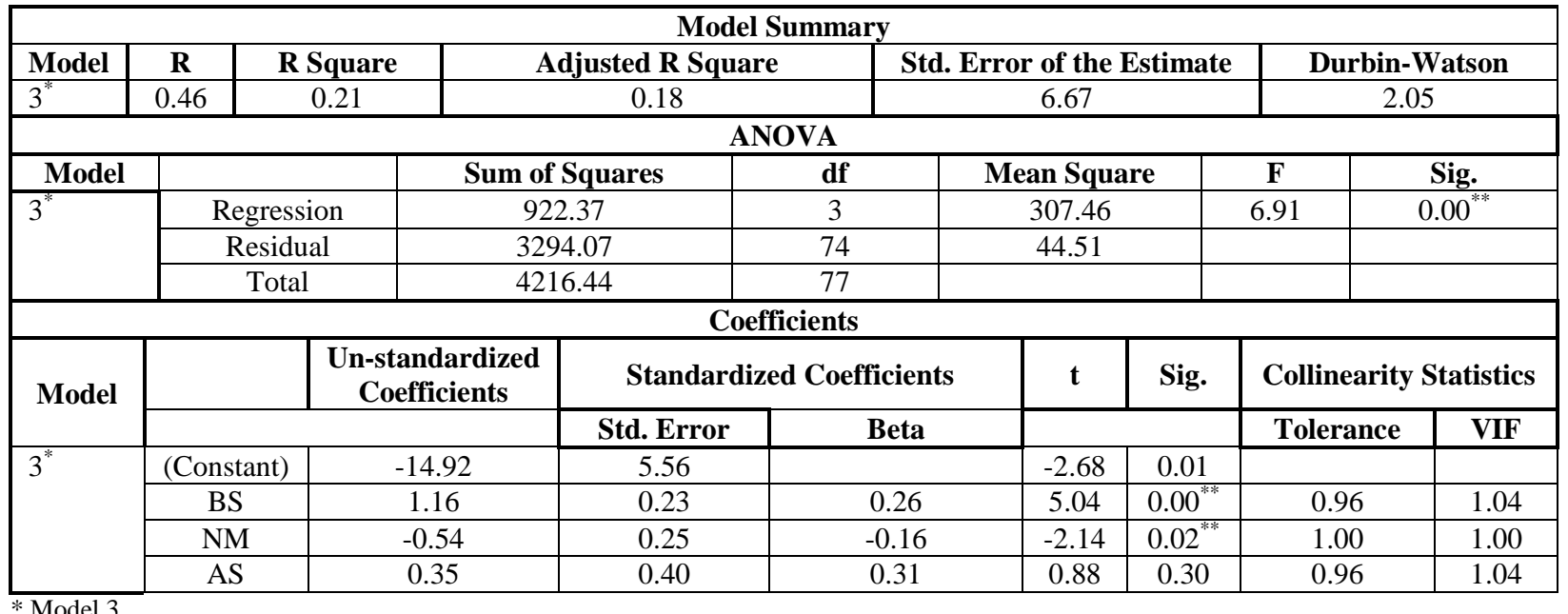

Model 3 is also significant at $1 \%$ level of significance. It shows that corporate governance variables have significant influence on earning per share. As far as board size and the number of meetings are concerned the coefficients of both variables are also positively and negatively significant at $5 \%$ level of significance respectively similar to model 1 and 2. 


\section{CONCLUSION AND DISCUSSION}

The primary contribution of this paper to the literature is to find a reverse relationship between board size and firm performance. For developed countries it is argued in various studies that a small board size is beneficial for firm performance. But in this study it is concluded that a large board size is good for firm performance in the context of under developing countries, like Pakistan (Finkelstein \& Hambrick, 1996; Johnson, Daily, \& Ellstrand, 1996; Zahra \& Pearce, 1989).

Statistical results also supported our argument that a large board size accelerates the performance of the enterprises. It is very difficult to manage a large board in firms which causes delays in executing important decisions and creates hidden costs for firms but at the same time it is very beneficial for firm performance for countries like Pakistan in which Seith and Vehdra exploit the rights of minor shareholders. In a situation where board size is small, these Seith or Vehdra appoints their likeminded persons as director and abuse the rights of minor shareholders. This argument is supported by the results shown in the Table 1, which shows that banks having smaller board sizes have not performed as well as those banks that have large board sizes in the case of state owned banks. In the case of private banks they are quite smart as compared to the state-owned banks as they have larger board sizes and encourage transparency, innovation, and accountability to enhance their performance.

In concluding the argument, this study is idealizing the resource dependent theory that is a larger board size can enhance the performance of a company (Alexander, Fennell, \& Halpern, 1993; Goodstein, Gautam, \& Boeker, 1994; Mintz-berg, 1983; Pfeffer, 1972, 1973; Pfeffer \& Salancik, 1978; Provan, 1980).

\section{AUTHOR INFORMATION}

Maria Malik is a Doctoral Candidate at the School of Management, Xi'an Jiaotong University. Her research interests focus on banking, human resource, and governance practices. E-mail: maria_malik20066@yahoo.com

Di-fang Wan (PhD, Xi'an Jiaotong University) is a Professor of Organization Management at the School of Management, Xi'an Jiaotong University, China. He received his PhD degree in Management through Xi'an Jiaotong University/University of Alberta Joint PhD Program under the Canada-China Management Education Project. His research interests include corporate governance, merger and acquisition, organization innovation, and experimental research. He has published numerous papers in Chinese leading journals and has published in the Journal of High Technology Management Research, International Journal of Health Care Finance and Economics, Management and Organization Review, and Asia Pacific Journal of Management. He has been in charge of several projects funded by the National Science of Foundation of China (NSFC). E-mail: dfwan@ mail.xjtu.edu.cn

Muhammad Ishfaq Ahmad is Lecturer of Finance at Lahore Business School, The University of Lahore. His research interests include, corporate governance, banking, and corporate finance. E-mail: $\underline{m}$ _ishfaq452@yahoo.com

Muhammad Akram Naseem is currently doing his $\mathrm{PhD}$ in Financial Management. He has more than ten years of teaching experience at University level and profession experience at Central Bank. Currently, he served as an Assistant Professor of Statistics at Lahore Business School, The University of Lahore. Now, he is on study leave. E-mail: iqra4ever@gmail.com

Ramiz ur Rehman is currently doing his $\mathrm{PhD}$ in Financial Management. He has ten years of teaching experience at University level. He also served as an Assistant Professor of finance at Lahore Business School, The University of Lahore. Now, he is on study leave. E-mail: ramiz_rehman@ hotmail.com (Corresponding author)

\section{REFERENCES}

1. Aebi, V., Sabato, G., \& Schmid, M. (2010). Risk management, corporate governance, and bank performance in the financial crisis. 10th GUBERNA European Corporate Governance conference in Brussels. 
2. Anderson, R. C., \& Reeb, D. M. (2003). Founding-family ownership and firm performance: Evidence from the S\&P 500. Journal of Finance, 58, 1301-1328.

3. Anderson, R. C., \& Reeb, D. M. (2004). Board composition: balancing family influence in S\&P 500 firms. Administrative Science Quarterly, 49, 209-237.

4. Beck, T., Cull, R., \& Jerome, A. (2005). Bank privatization and performance: Empirical evidence from Nigeria. Journal of Banking and Finance, 29, 2355-2379.

5. Belkhir, M. (2009). Board of directors' size and performance in the banking industry. International Journal of Managerial Finance, 5(2), 201-221.

6. Berger, A. N., Hasan, I., \& Klapper, L. F. (2004). Further evidence on the link between finance and growth: An international analysis of community banking and economic performance. Journal of Financial Services Research, 25, 169-202.

7. Bhagat, S., \& Black, B. (2002). The non-correlation between board independence and long-term performance. Journal of Corporation Law, 27(2), 231-43.

8. Bhattacharya, A., Lovell, C. A. K., \& Sahay, P. (1997). The impact of liberalization on the productive efficiency of Indian commercial banks. European Journal of Operational Research, 98, 332-345.

9. Bonin, J., Hasan, I., \&Wachtel, P. (2005). Bank performance, efficiency, and ownership in transition countries. Journal of Banking and Finance, 29, 31-53.

10. Borokhovich, K., Parrino, R., \& Trapani, T. (1996). Outside directors and CEO selection. Journal of Financial and Quantitative Analysis, 31, 337-355.

11. Boubakri, N., Cosset, J.-C., Fischer, K., \&Guedhami, O. (2005). Privatization and bank performance in developing countries. Journal of Banking and Finance, 29, 2015-2041.

12. Boubakri, N., Cosset, J.-C., \& Guedhami, O. (2009). From state to private ownership: Issues from strategic industries. Journal of Banking and Finance, 33, 367-379.

13. Brickley, A., \& James, C. M. (1987). The takeover market, corporate board composition, and ownership structure: The case of banking. Journal of Law and Economics, 30(1), 161-180.

14. Brickley, J., Coles, J., \& Terry, R. (1994). Outside directors and the adoption of poison pills. Journal of Financial Economics, 34, 371-390.

15. Byrd, J., \& Hickman, A. (1992). Do outside directors monitor managers? Evidence from tender offer bids. Journal of Financial Economics, 32, 195-221.

16. Carleton, W., Nelson, J., \& Weisbach, M. (1998). The in\#uence of institutions on corporate governance through private negotiations: Evidence from TIAA-CREF. Journal of Finance, 53, 133-1362.

17. Claessens, S., Djankov, S., Fan, J. P. H., \& Lang, L. H. P. (2002). Disentangling the incentive and entrenchment effects of large shareholdings. Journal of Finance, 57, 2741-2771.

18. Clarke, G. R. G., Cull, R., \& Shirley, M. M. (2005). Bank privatization in developing countries: A summary of lessons and findings. Journal of Banking and Finance, 29, 1905-1930.

19. Cotter, J., Shivdasani, A., \& Zenner, M. (1997). Do independent directors enhance target shareholder wealth during tender o!ers? Journal of Financial Economics, 43, 195-218.

20. Cronqvist, H., \& Nilsson, M. (2003). Agency costs of controlling minority shareholders. Journal of Financial and Quantitative Analysis, 38, 695-719.

21. Dalton, D. R., Daily, C. M., Ellstrand, A. E., \& Johnson, J. L. (1998). Meta-analytic reviews of board composition, leadership structure, and financial performance. Strategic Management Journal, 19(3), 269290.

22. de Andres, P., \& Vallelado, E. (2008). Corporate governance in banking: The role of the board of directors. Journal of Banking \& Finance, 32, 2570-2580.

23. Demsetz, H., \& Lehn, K. (1985). The structure of corporate ownership: causes and consequences. Journal of Political Economy, 93, 1155-1177.

24. Faccio, M., \& Lang, L. H. P. (2002). The ultimate ownership of Western European corporations. Journal of Financial Economics, 65(3), 365-395.

25. Hermalin, B., \& Weisbach, M. (1988). The effects of board composition and direct incentives on firm performance. Financial Management, 20(4), 101-12.

26. Hermalin, B., \& Weisbach, M. (1988). The determinants of board composition. Rand Journal of Economics, 19, 589-606.

27. Huson, M. (1997). Does governance matter? Evidence from CalPERS interventions. (Unpublished working paper). University of Alberta. 
28. Isik, I., \& Hassan, M. K. (2002). Technical, scale and allocative efficiencies of Turkish banking industry. Journal of Banking and Finance, 26, 719-766.

29. Jensen, M. (1993). The modern industrial revolution, exit and the failure of internal control systems. Journal of Finance, 48, 831-880.

30. Klein, A. (2002). Audit committee, board of director characteristics, and earnings management. Journal of Accounting and Economics, 33, 375-400.

31. Lin, J. W., Li, J. F., \& Yang, J. S. (2006). The effect of audit committee performance on earnings quality. Managerial Auditing Journal, 21(9), 921-933.

32. Lin, X., \& Zhang, Y. (2009). Bank ownership reform and bank performance in China. Journal of Banking and Finance, 33, 20-29.

33. Maury, B. (2006). Family ownership and firm performance: Empirical evidence from Western European corporations. Journal of Corporate Finance, 12, 321-341.

34. McConaughy, D. L., Walker, M. C., Henderson Jr., G. V., \& Mishra, C. S. (1998). Founding family controlled firms: Efficiency and value. Review of Financial Economics, 7, 1-19.

35. Morck, R. K., Shleifer, A., \& Vishny, R. W. (1988). Management ownership and market valuation: An empirical analysis. Journal of Financial Economics, 20, 293-315.

36. Nesbitt, S. (1994). Long term rewards from shareholder activism: a study of the CalPERS e!ect. Journal of Applied Corporate Finance, 6, 75-80.

37. Rosly, S, A., \& Mohd Afandi Abu Bakar. (2003). Performance of Islamic and mainstream banks in Malaysia. International Journal of Social Economics, 30(12), 1249-1265.

38. Smith, M. (1996). Shareholder activism by institutional investors: Evidence from CalPERS. Journal of Finance, 51, 227-252.

39. Strickland, D., Wiles, K., \& Zenner, M. (1996). A requiem for the USA: Is small shareholder monitoring elective? Journal of Financial Economics, 40, 319-338.

40. Tandelilin, E. (2007). Corporate governance, risk management, and bank performance: Does type of ownership matter? (Eadn working paper no. 34).

41. Vafeas, N. (1999). Board meeting frequency and firm performance. Journal of Financial Economics, 53 , 113-142.

42. Vallelado, E., \& Andres, P. (2008). corporate governance in banking: The role of the board of directors. Journal of Banking \& Finance, 32, 2570-2580.

43. Villalonga, B., \& Amit, R. (2006). Benefits and costs of control-enhancing mechanisms in U.S. family firms. (Working Paper). Harvard Business School. May.

44. Xie, B., Davidson, W. N., \& DaDalt, P. J. (2003). Earnings management and corporate governance: The role of the board and the audit committee. Journal of Corporate Finance, 9, 295-316.

45. Yang, J. (2011). Does adopting high-standard corporate governance increase firm value? An empirical analysis of Canadian companies. International Business \& Economics Research Journal, 10.

46. Yudistira, D. (2004). Efficiency in Islamic banking: An empirical analysis of eighteen banks. Islamic Economic Studies, 12(1). 


\section{NOTES}

